\title{
LOW LEAD EXPOSURE DURING FOETAL AND EARLY POSTNATAL LIFE IMPAIRS PASSIVE AVOIDANCE LEARNING IN ADULTHOOD IN RATS
}

\author{
Rajashekar RAO BARKUR ${ }^{1}$, Muddanna S. RAO ${ }^{2}$, and Laxminarayana K. BAIRY ${ }^{3}$ \\ Department of Biochemistry, Melaka Manipal Medical College, Manipal University, Manipal, Indial, Department of \\ Anatomy, Faculty of Medicine, Kuwait University, Kuwait ${ }^{2}$, Department of Pharmacology, Kasturba Medical College, \\ Manipal University, Manipal, India ${ }^{3}$
}

Received in September 2010

CrossChecked in October 2010

Accepted in April 2011

\begin{abstract}
This follow-up study investigated the effects of low-level lead exposure during prenatal and early postnatal period on learning and memory in rats immediately after exposure has ceased at weaning and later in their adulthood. Male Wistar-derived rats were exposed to lead (as $0.2 \%$ lead acetate solution) through their mothers during pregnancy and lactation until they were weaned. Mothers of control rats were given tap water during pregnancy and lactation. All pups were weaned on tap water at 21 days of age and were followed up until 120 days old. Low-level lead exposure did not affect their body weight at any time during the experiment. Blood lead in the exposed rats was significantly higher on postnatal day 22 and dropped to control values by day 120 . Passive avoidance test showed impaired memory retention in the exposed rats on postnatal days 25 and 120 . This suggests that exposure to low-lead levels during foetal and early postnatal development of brain tissue can cause memory impairment that lasts into adulthood.
\end{abstract}

KEY WORDS: blood lead, developing brain, hippocampus, lead acetate, learning, memory

Lead is a cumulative toxin (1). Routes of exposure are lead-contaminated water, soil, air, and food (2). Although environmental lead pollution has significantly decreased thanks to the ban of leaded gasoline in most of industrialised countries, lead is still a major public health problem in Third World nations. The threat of lead poisoning in developing countries is still present due to contamination from industrial waste production, lead battery recycling plants, printing press, leadbased pigments and paints, silver refining industry, vehicle emission, and folk medicines (3).

The developing nervous system is especially vulnerable to lead-induced changes that may hamper brain development and result in neurological deficit (4-6). In humans, the critical stage of brain development begins in the last trimester of uterine life and continues into the first two years of life. In rats it ends at the age of three to four weeks. During this period, the brain grows rapidly and undergoes major developmental and biochemical changes (6). Hippocampus, which plays an important role in conscious recollection and explicit memory expression, seems to be the most affected by lead poisoning $(7,8)$.

Even though the exact mechanism by which lead acts as a neurotoxin remains unclear, in exposed children it induces deficits in learning and memory (9). Neurobehavioral deficits in the domains of intelligence, reaction time, and attention have consistently been shown in urban children exposed to low lead levels (9). Monkeys exposed to lead during infancy showed impairment in spatial learning and memory tasks, while monkeys exposed to lead from 
infancy to adulthood performed poorly in both spatial and non-spatial tasks $(10,11)$.

Findings in adult rats following lead exposure during prenatal and postnatal development are controversial. Jaako-Movits et al. (12) found that lead exposure in suckling pups impaired contextual fear conditioning and reduced hippocampal neurogenesis as they reached adulthood. Similarly, Murphy et al. (13) found deficits associated with memory consolidation in adult rats exposed to lead in the early postnatal period. Others, in contrast, found that maternal lead exposure did not impair adult rats' memory retention $(14,15)$ and spatial learning $(16)$. Prospective studies in humans and experimental animals confirmed lead-induced behavioural and cognitive changes by correlating them with persistent elevated perinatal blood lead levels that may endure throughout the postnatal development, adolescence, and even lifetime (17-19).

Although there is ample evidence about the effects of lead exposure on cognitive and behavioural deficits in children, information on long-term consequences in adulthood due to perinatal lead exposure are inconsistent. The aim of this study was to assess the effect of prenatal and early postnatal (up to 21 day) low-level lead exposure on memory retention in young adult (120 day-old) rats by testing passive avoidance learning and memory.

\section{MATERIAL AND METHODS}

\section{Animals}

The use of animals in this study was approved by the institutional ethics committee. We used threemonth-old in-house bred Wistar-based male and female albino rats and their F1 generation male pups. Average body weights at baseline were $(181 \pm 2.0) \mathrm{g}$ in females and $(195.3 \pm 1.5) \mathrm{g}$ in males. Weight gains in both control and lead-exposed mother rats during gestation were similar. Mean body weight of male pups used for control and lead-exposed group at age of 30 days was $(50.9 \pm 1.40) \mathrm{g}$ and $(50.1 \pm 1.17) \mathrm{g}$, respectively.

Animals were maintained in the 12:12-hour light and dark cycle in animal facilities, with water and food (Amurut feed supplies, Puna, India) supplied ad libitum. In a preliminary study, we determined water intake by control and lead-exposed rats kept in separate cages. Each rat (control or lead-exposed) consumed $(25.12 \pm 2.5) \mathrm{mL}$ of water a day.

Animals were housed in polypropylene cages $(37 \mathrm{~cm} \times 21.5 \mathrm{~cm} \times 14 \mathrm{~cm})$ with a wire mesh lid. Sterile paddy husk was used for bedding. After weaning, control and lead-exposed pups were kept in separate cages, three per cage.

To know the day of conception and gestational age, all female rats were subjected to vaginal smear test. The rats in the oestrous cycle were mated with young healthy male rats overnight ( 2 males and 2 females per cage). Next morning, vaginal smears were checked and the presence of sperm in the smear confirmed mating. The day with the positive sperm finding was taken as day 1 of gestation.

\section{Experimental design}

Lead was administered as $0.2 \%$ lead acetate solution to pregnant rats according to the protocol published previously $(12,14)$. This protocol has been shown to alter neuronal arborisation and astrocyte structure in pups without affecting their growth (20). Pups were exposed to lead via their mothers from day 1 of gestation to postnatal day 21. Pregnant mothers were divided in the control $(\mathrm{N}=6)$ and lead-exposed $(\mathrm{N}=6)$ group. The lead-exposed group had free access to bottles containing $0.2 \%(\mathrm{w} / \mathrm{v})$ lead acetate solution (Merk Chemical Co., India) in tap water with $0.5 \mathrm{~mL}$ $\mathrm{L}^{-1}$ glacial acetic acid (Nice chemicals, India) to prevent precipitation of lead acetate.

Pups born to the lead-exposed mother rats had access to the same drinking solution as their mothers until weaning on postnatal day 21 . On postnatal day 22 , one to two male rat pups from each control and lead-exposed mother rat (totalling 9 control and 9 lead-exposed pups, respectively) were selected at random and housed in separate cages (three per cage). From postnatal day 22 through 120, all received tap water. The male pups were weighed at birth and at monthly intervals thereafter.

\section{Blood lead analysis}

Blood was collected from orbital veins in heparinised vacutainers on postnatal days 22 and 120 . One hundred microlitres of blood was mixed with $2.9 \mathrm{~mL}$ of metexchange reagent using a micro-pipettor and allowed to stand for $24 \mathrm{~h}$. Blood lead was determined by anodic stripping voltammetry using an ESA-3010B lead analyzer (21). 


\section{Passive avoidance learning test}

To test memory retention rats were subjected to the passive avoidance test on postnatal days 25 and 120 (22). The passive avoidance apparatus was a wooden box with a larger, bright compartment and a smaller, dark compartment with grid floor, which was attached to a shock source. At the beginning of the test, rats were allowed to explore both compartments for five minutes. This was followed by three test trials of five minutes each. In each trial, we measured the time rats spent in each compartment. In the fourth trial, the rats received three strong foot shocks $(50 \mathrm{~Hz}, 1.5$ $\mathrm{mA}$ for $1 \mathrm{~s}$ ) at five-second intervals as soon as they stepped into the dark compartment and then they were returned to the home cage. This is known as exploration and learning. Twenty-four hours later, the rats were placed into the bright compartment and we measured the time for them to enter the dark compartment for the first time (latency) and the total time spent in each compartment. The test lasted $180 \mathrm{~s}$. Normally, rats shy from the dark compartment, where they received shock on the previous day. This, so called retention test was repeated after $48 \mathrm{~h}$. Lower latency to enter into dark compartment and less time spent in bright compartment suggest poor memory retention (22).

\section{Statistical analysis}

The numerical data are expressed as arithmetic mean \pm SEM. Differences between the groups were tested using the unpaired Student's $t$-test and significance was set at $P<0.05$.

\section{RESULTS AND DISCUSSION}

\section{Body weight}

Table 1 shows average birth weight and body weights measured at monthly intervals in control and lead-exposed pups. No differences were found at any measured interval. These results suggest that lead exposure did not impair pup growth.

\section{Blood lead concentration}

Blood lead concentration measured on postnatal day 22 was significantly higher in lead-exposed than in control pups $\left[(31.3 \pm 0.89) \mu \mathrm{g} \mathrm{dL}{ }^{-1} v s .(0.266 \pm 0.03)\right.$ $\mu \mathrm{g} \mathrm{dL}{ }^{-1}$, respectively]. It returned to normal by postnatal day 120 (Figure 1).

\section{Passive avoidance learning}

In exploration trials on postnatal day 25 , before receiving foot shocks (learning), the pups in either group showed no significant difference in time spent in the dark and bright compartment and in the number of entries into the dark compartment (data not shown).

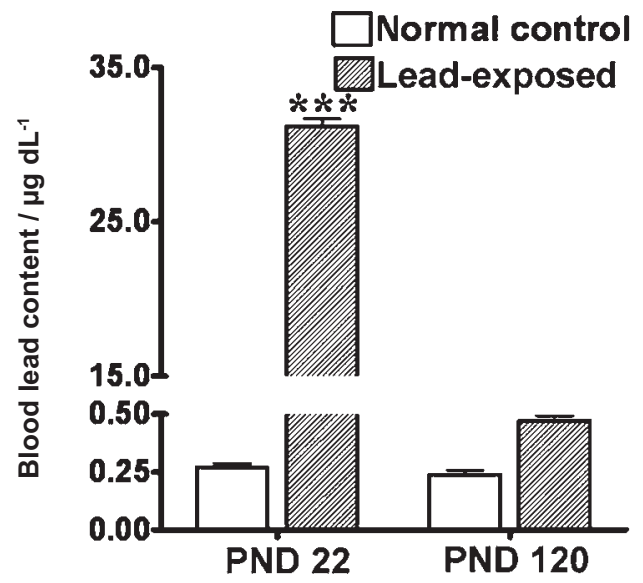

Figure1 Blood lead concentrations ( $\mu g \mathrm{~d} \mathrm{~L}^{-1}$ of whole blood) in male control and lead-exposed rats on postnatal days (PND) 22 and 120. Exposure to $0.2 \%$ lead acetate solution lasted from gestation day 1 through weaning on postnatal day 21. Each bar represents arithmetic mean \pm SEM ( $N=9$ per group). $* * * P<0.001$ (Student's t-test)

Table 1 Body weight of control and lead-exposed male rats. Exposure to $0.2 \%$ lead acetate solution lasted from gestation day 1 through weaning on postnatal day 21.

\begin{tabular}{lcccccc}
\hline \multirow{2}{*}{ Groups } & & \multicolumn{5}{c}{ Body weight $/ \mathbf{g}$} \\
\cline { 3 - 7 } & $\mathbf{N}$ & \multicolumn{5}{c}{ Postnatal day } \\
\cline { 2 - 7 } & & Birth & $\mathbf{3 0}$ & $\mathbf{6 0}$ & $\mathbf{9 0}$ & $\mathbf{1 2 0}$ \\
\hline Control & 9 & $5.82 \pm 0.08$ & $51.33 \pm 1.49$ & $157 \pm 1.93$ & $243 \pm 5.50$ & $289.9 \pm 4.40$ \\
\hline Lead-exposed & 9 & $5.95 \pm 0.05$ & $50.78 \pm 1.07$ & $156 \pm 4.84$ & $254 \pm 7.02$ & $298.2 \pm 4.20$ \\
\hline
\end{tabular}

The data are presented as arithmetic mean $\pm S E M$. 
The retention test performed $24 \mathrm{~h}$ and $48 \mathrm{~h}$ after learning showed significantly lower latency in leadexposed pups than in controls (Figure 2). In the first retention test, lead-exposed rats entered the dark compartment after $31 \mathrm{~s}$ (controls after $117 \mathrm{~s}$ ). In the second retention test that time was even shorter $(21 \mathrm{~s}$ in lead-exposed $v s .81 \mathrm{~s}$ in controls). In addition, leadexposed rats spent significantly less total time in the bright compartment on both retention tests than controls.
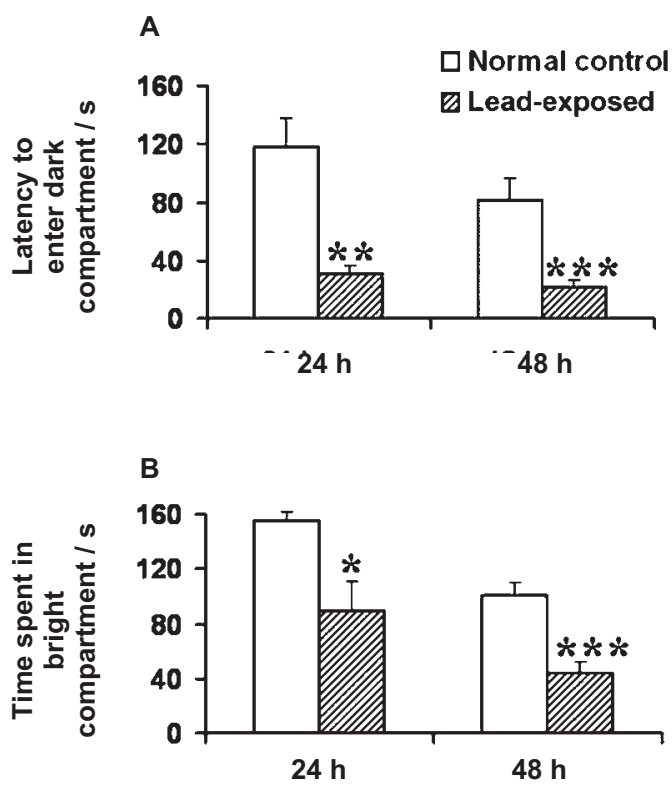

Figure 2 Passive avoidance learning retention tests in 25-oldday rats. A. Latency to enter the dark compartment (in seconds), B. Total time spent in the bright compartment (in seconds) during the 180-s passive avoidance retention test $24 \mathrm{~h}$ and $48 \mathrm{~h}$ after learning. Each bar represents arithmetic mean $\pm S E M(N=9$ per group). ${ }^{*} P<0.05, * * P<0.01$, ${ }^{*} * * P<0.001$ (Student's t-test).

In exploration trials repeated on postnatal day 120 , the groups showed no significant difference in the time spent in the dark and bright compartment and in the number of entries into the dark compartment. The retention test performed $24 \mathrm{~h}$ and $48 \mathrm{~h}$ after the foot shocks showed significantly lower latency to enter the dark compartment in lead-exposed rats than in controls (Figure 3). In the first retention test, lead-exposed rats entered the dark compartment after $21 \mathrm{~s}$ (controls after $101 \mathrm{~s})$. In the second retention test, that time was again shorter $(9 \mathrm{~s}$ in lead-exposed $v s .58 \mathrm{~s}$ in controls. Furthermore, the lead-exposed rats again spent significantly less total time in the bright compartment on both retention tests.
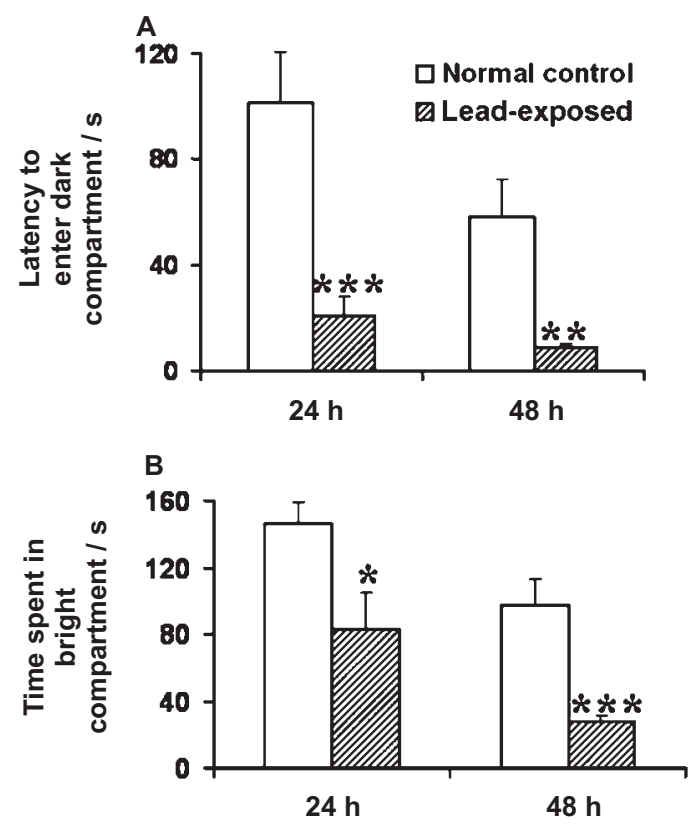

Figure 3 Passive avoidance learning retention tests in 120old-day rats. A. Latency to enter the dark compartment (in seconds) $24 \mathrm{~h}$ and $48 \mathrm{~h}$ after learning. B. Total time spent in the bright compartment (in s) during the 180-s passive avoidance retention test $24 \mathrm{~h}$ and $48 \mathrm{~h}$ after learning. Each bar represents arithmetic mean $\pm S E M(N=9$ per group). $* P<0.05, * * P<0.01$, $* * * P<0.001$ (Student's t-test).

These results indicate impaired memory retention. This may be associated with lead-induced impairments of the hippocampus. Hippocampus plays an important role in both spatial and contextual learning. It was shown that the passive avoidance tasks in rats require a contribution from hippocampus and other parts of limbic system $(23,24)$. Passive avoidance tests or conditioned avoidance tests have been used in several studies to assess memory or retention and also retrieval after or during other treatments (25-27).

In this study we observed that the behaviour of both control and lead-exposed rats during exploration and before giving the foot shock was similar, indicating no lead-induced deficit in exploration behaviour. After the foot shock, lead-exposed rats showed lower latency to enter the dark compartment than controls, which may be due to memory impairment. Alternatively, short latency may be due to lead-induced hyperactivity, as reported by Gong and Evans (28). However, our experimental design did not test lead-induced hyperactivity and exploration as an alternative to memory impairment. In addition, similar exploratory behaviour in both groups before the foot shock seems to rule out this interpretation. 
Exposure to low levels of inorganic lead during early development has been associated with longlasting behavioural abnormalities and cognitive deficits in children and young experimental animals $(19,29)$. In rats exposed to lead from gestation to weaning, Moreira et al. (30) found memory impairment only on postnatal day 23 , but not on day 70 . In contrast, our study showed learning impairment on both postnatal days 25 and 120 . One reason for this discrepancy could be lead doses used. Moreira et al. (30) used $0.50 \mathrm{~g} \mathrm{~L}^{-1}$ of lead as lead-acetate solution. Structural changes caused in the brain by $0.50 \mathrm{~g} \mathrm{~L}^{-1}$ of lead might have been reversed by the time animals reached the age of 70 days.

Jett et al. (31) suggested that continuous lead exposure of rats from gestation to adulthood resulted in an age-dependent impairment in performance in the Morris water maze. It has been demonstrated that when exposed to lead continuously during development, $N$-methyl-D-aspartate (NMDA) and muscarinic cholinergic receptors are altered in the hippocampus of rats at 14 days of age (32).

Lead exposure has recently been shown to disturb the aminergic system in the cerebral cortex, cerebellum, and hippocampus and to contribute to cognitive and behavioural impairments in rats (33). Jaako-Movits et al. (12) demonstrated that exposure to lead during early development persistently inhibited neurogenesis and altered the pattern of differentiation of new cells in the dentate gyrus of rat hippocampus, which could, at least partly, contribute to behavioural and cognitive impairments observed in adulthood. Other studies have also shown weaker nerve growth factor gene expression in the hippocampus of adult rats exposed to lead after weaning (8) or during lifetime (34).

Irrespective of mechanism (s) of action involved, long-term neurodevelopmental consequences of lead exposure appear to be related to persistent deficits associated specifically with hippocampus and limbic system memory consolidation. To conclude, our study has shown that low-level lead exposure during the critical period of brain development and maturation can impair learning and memory in rats for long after lead exposure has stopped.

\section{REFERENCES}

1. Michael R. Historical perspective on lead biokinetic models Environ Health Perspect 1998;106 (Suppl 6):1461-5.

2. Tong S, von Schirnding YE, Prapamontol T. Environmental lead exposure: a public health problem of global dimensions. Bull World Health Organ 2000;78:1068-67.
3. Henry F. International environmental health for the pediatrician: Case study of lead poisoning. Pediatrics 2003;112:259-64.

4. Evans HL. Cognitive and behavioral manifestations of Lead. In: Nass RD, Frank Y, editors. Cognitive and behavioral abnormalities of pediatric diseases. New York (NY): Oxford University Press; 2010. p. 609-16.

5. Brent RL, Tanski S, Weitzman M. A Pediatric perspective on the unique vulnerability and resilience of the embryo and the child to environmental toxicants: The importance of rigorous research concerning age and agent. Pediatrics 2004;113 (Suppl 4):935-44.

6. Rice D, Barone S Jr. Critical periods of vulnerability for the developing nervous system: evidence from humans and animal models. Environ Health Perspect 2000;108 (Suppl 3):511-33.

7. Broadbent NJ, Squire LR, Clark RE. Spatial memory, recognition memory, and the hippocampus. Proc Natl Acad Sci USA 2004;101:1451520.

8. Schneider JS, Lee MH, Anderson DW, Zuck L, Lidsky TI. Enriched environment during development is protective against lead-induced neurotoxicity. Brain Res 2001;896:4855.

9. Chiodo LM, Covington C, Sokol RJ, Hannigan JH, Jannise J, Ager J, Greenwald M, Delaney-Black V. Blood lead levels and specific attention effects in young children. Neurotoxicol Teratol 2007;29:53846.

10. Rice DC. Behavioral effects of lead in monkeys tested during infancy and adulthood. Neurotoxicol Teratol 1992;14:23545.

11. Rice DC. Lead-induced behavioral impairment on a spatial discrimination reversal task in monkeys exposed during different periods of development. Toxicol Appl Pharmacol 1990;106:32733.

12. Jaako-Movits K, Zharkovsky T, Romantchik O, Jurgenson M, Merisalu E, Heidmets LT, Zharkovsky A. Developmental lead exposure impairs contextual fear conditioning and reduces adult hippocampal neurogenesis in the rat brain. Int J Dev Neurosci 2005;23:62735.

13. Murphy KJ, Regan $\mathrm{cm}$. Low-level lead exposure in the early postnatal period results in persisting neuroplastic deficits associated with memory consolidation. J Neurochem 1999;72:2099-104.

14. Chen HH, Ma T, Paul IA, Spencer JL, Ho IK. Developmental lead exposure and two-way active avoidance training alter the distribution of protein kinase $\mathrm{C}$ activity in the rat hippocampus. Neurochem Res 1997;22:1119-25.

15. Chen H, Ma T, Ho IK. Effects of developmental lead exposure on inhibitory avoidance learning and glutamate receptors in rats. Environ Toxicol Pharmacol 2001;9:185-91.

16. Gilbert ME, Kelly ME, Samsam TE, Goodman JH. Chronic developmental lead exposure reduces neurogenesis in adult rat hippocampus but does not impair spatial learning. Toxicol Sci 2005; 86:365-74.

17 Lilienthal H, Winneke G, Ewert T. Effects of lead on neurophysiological and performance measures: animal and human data. Environ Health Perspect 1990;89:21-5.

18. Needleman HL, Schell A, Bellinger D, Leviton A, Allred EN. The long term effects of exposure to low doses of lead in childhood. An 11-year follow-up report. N Engl J Med 1990;322:83-8. 
19. Finkelstein Y, Markowitz ME, Rosen JF. Low-level leadinduced neurotoxicity in children: an update on central nervous system effects. Brain Res Rev 1998;27:168-76.

20. Chang W, Chen J, Wei QY, Chen XM. Effects of Brn-3a protein and RNA expression in rat brain following low-level lead exposure during development on spatial learning and memory. Toxicol Lett 2006;164:63-70.

21. Kuruvilla A, Pillay VV, Venkatesh T, Adhikari P, Chakrapani M, Clark CS, D'Souza H, Menezes G, Nayak N, Clark R, Sinha S. Portable lead analyzer to locate source of lead. Indian J Pediatr 2004;71:495-9.

22. Bures J, Buresová O, Huston JP. Techniques and basic experiments for the study of brain and behavior. $2^{\text {nd }}$ ed. Amsterdam: Elsevier; 1983.

23. Aggleton JP, Brown MW. Episodic memory, amnesia, and the hippocampal-anterior thalamic axis. Behav Brain Sci 1999;22:425-89.

24. Aggleton JP, Vann SD, Oswald CJ, Good M. Identifying cortical inputs to the rat hippocampus that subserve allocentric spatial processes: a simple problem with a complex answer. Hippocampus 2000;10:466-74.

25. Kumar KB, Karanth KS. Enhanced retrieval of unpleasant memory in helpless rats. Biol Psychiatry 1991;30:493-501.

26. Przybyslawski J, Roullet P, Sara SJ. Attenuation of emotional and nonemotional memories after their reactivation: Role of $\beta$ adrenergic receptors. J Neurosci 1999;19:6623-8.

27. Narayanan SN, Kumar RS, Potu BK, Nayak S, Bhat PG, Mailankot M. Effect of radio-frequency electromagnetic radiations (RF-EMR) on passive avoidance behaviour and hippocampal morphology in Wistar rats. Ups J Med Sci 2010;115:91-6.

28. Gong Z, Evans HL. Effect of chelation with mesodimercaptosuccinic acid (DMSA) before and after the appearance of lead-induced neurotoxicity in the rat. Toxicol Appl Pharmacol 1997;144:205-14.

29. Bellinger D, Sloman J, Leviton A, Rabinowitz M, Needleman HL, Waternaux C. Low-level lead exposure and children's cognitive function in the preschool years. Pediatrics 1991;87:219-27.

30. Moreira EG, Vassilieff I, Vassilieff VS. Developmental lead exposure: behavioral alterations in the short and long term. Neurotoxicol Teratol 2001;23:489-95.

31. Jett DA, Kuhlmann AC, Farmer SJ, Guilarte TR. Age dependent effects of developmental lead exposure on performance in the Morris water maze. Pharmacol Biochem Behav 1997;57:271-9.

32. Jett DA, Guilarte TR. Developmental lead exposure alters $\mathrm{N}$-methyl-D-aspartate and muscarinic cholinergic receptors in the rat hippocampus: an autoradiographic study. Neurotoxicology 1995; 16:7-18.

33. Devi CB, Reddy GH, Prasanthi RP, Chetty CS, Reddy GR. Developmental lead exposure alters mitochondrial monoamine oxidase and synaptosomal catecholamine levels in rat brain. Int J Dev Neurosci 2005;23:375-81.

34. Cory-Slechta DA, Stern S, Weston D, Allen JL, Liu S. Enhanced learning deficits in female rats following life time $\mathrm{Pb}$ exposure combined with prenatal stress. Toxicol Sci 2010;117:427-38. 


\section{Sažetak}

\section{IZLOŽENOST ŠTAKORA NISKIM RAZINAMA OLOVA TIJEKOM FETALNOG I RANOGA POSTNATALNOG RAZVOJA ŠTETI UČENJU PASIVNIM IZBJEGAVANJEM KAZNE KASNIJE U ODRASLOJ DOBI}

Cilj je ovoga prospektivnog istraživanja bio utvrditi kako izloženost niskim razinama olova tijekom gestacije i ranoga postnatalnog razvoja utječe na učenje i pamćenje u štakora odmah nakon prestanka izloženosti (odbijanjem od sise) te kasnije u odrasloj dobi. Mužjaci štakora izloženi su olovu u obliku 0,2 \%-tne otopine olovova acetata preko majke tijekom gestacije te za cijeloga trajanja laktacije sve do odbijanja od sise. Sve to vrijeme majke kontrolnih štakora dobivale su vodu iz pipe. Svi su štakorčići odbijeni od sise 21 dan nakon okota i otada piju vodu iz pipe. Praćeni su do 120. dana života. Izloženost niskim razinama olova nije dovela do razlika u tjelesnoj težini između izloženih i kontrolnih štakorčića. Razine olova u krvi bile su značajno više u izloženih štakora 22 dana od okota, da bi do 120. dana pale na razinu u kontrolnih štakora. Test pasivnoga izbjegavanja pokazao je oštećenje pamćenja u izloženih štakora 25. i 120. dana nakon okota. To potvrđuje da izloženost niskim razinama olova tijekom fetalnoga i ranoga postnatalnog razvoja moždanog tkiva može dovesti to oštećenja u pamćenju koje traje sve do odrasle dobi.

KLJUČNE RIJEČI: hipokampus, mozak u razvoju, olovov acetat, olovo u krvi, pamćenje, učenje

\section{CORRESPONDING AUTHOR:}

Laxminarayana K. Bairy

Professor of Pharmacology,

Kasturba Medical College,

Manipal University, Manipal,

Karnataka, India.

E-mail:klbairy@gmail.com 